\title{
Preemergence herbicides on weed control in elephant grass pasture
}

\author{
Controle de plantas daninhas em pastagem de capim-elefante \\ com herbicidas pré-emergentes
}

\author{
Alexandre Magno Brighenti ${ }^{1 *}$, Leonardo Henrique Ferreira Calsavara², Yago Vieira Guerra Varotto ${ }^{3}$ \\ 'Empresa Brasileira de Pesquisa Agropecuária/Embrapa, Embrapa Gado de Leite, Juiz de Fora, MG, Brasil \\ ${ }^{2}$ Empresa de Assistência Técnica e Extensão Rural/Emater, Coronel Xavier Chaves, MG, Brasil \\ ${ }^{3}$ Centro de Ensino Superior de Juiz de Fora/CES-JF, Juiz de Fora, MG, Brasil \\ *Corresponding author: alexandre.brighenti@embrapa.br \\ Received in July 17, 2016 and approved in September 28, 2016
}

\begin{abstract}
Elephant grass (Pennisetum purpureum Schum.) is an important forage crop that has been proposed as a potential feedstock for bioenergy production. However, weed interference is a major factor limiting elephant grass production. Field experiments were conducted in 2014 and 2015 to evaluate preemergence herbicides for selective weed control in an elephant grass pasture. Herbicide treatments included atrazine + S-metolachlor, atrazine + simazine, ametryn, ethoxysulfuron, S-metolachlor, diuron + hexazinone, sulfentrazone, imazethapyr, and atrazine at label use rates. Weedy and weed-free treatments were included. Atrazine $+S$-metolachlor, atrazine + simazine, ametryn, ethoxysulfuron, $\mathrm{S}$-metolachlor, sulfentrazone, and atrazine did not cause phytotoxicity on elephantgrass 35 days after treatment (DAT). However, diuron + hexazinone and imazethapyr were the most phytotoxic on elephantgrass, resulting in 81 and $70 \%$ phytotoxicity in 2014, and 7 and $6 \%$ phytotoxicity in 2015 respectively 35 DAT. All treatments provided effective weed control (>81\%) with the exception of ethoxysulfuron ( 0 and $11 \%$ in 2014 and 2015, respectively), and atrazine (59\% in 2014). These results show that atrazine + S-metolachlor, atrazine + simazine, ametryn, ethoxysulfuron, S-metolachlor, sulfentrazone, and atrazine were selectives when applied in preemergence in elephant grass pasture.
\end{abstract}

Index terms: Bioenergy; biofuel; napier grass; forage; Pennisetum purpureum.

\begin{abstract}
RESUMO
O capim-elefante (Pennisetum purpureum Schum.) é uma planta forrageira importante que tem sido proposta como matéria-prima potencial para a produção de bioenergia. No entanto, a interferência das plantas daninhas é um fator limitante na produção do capim-elefante. Experimentos de campo foram realizados em 2014 e 2015 para avaliar herbicidas aplicados em condições de pré-emergência para o controle seletivo de plantas daninhas em pastagem de capim-elefante. Os tratamentos herbicidas incluíram atrazine + S-metolachlor, atrazine + simazine, ametryn, ethoxysulfuron, S-metolachlor, diuron + hexazinone, sulfentrazone, imazethapyr e atrazine em doses normalmente recomendadas no rótulo. Foram incluídas as testemunhas sem capina e capinadas. Atrazine + S-metolachlor, atrazine + simazine, ametryn, ethoxysulfuron, $S$-metolachlor, sulfentrazone e atrazine não causaram fitotoxicidade em capim-elefante aos 35 dias após os tratamentos (DAT). No entanto, diuron + hexazinone e imazethapyr foram os mais fitotóxicos ao capim-elefante, resultando em 81 e 70\% de fitotoxicidade em 2014, e 7 e 6\% em 2015, aos 35 DAT, respectivamente. Todos os tratamentos de controle de plantas daninhas foram eficazes (> 81\%) com a exceção de ethoxysulfuron (0 e 11\%, em 2014 e 2015, respectivamente) e atrazine (59\%, em 2014). Estes resultados mostram que os herbicidas atrazine + S-metolachlor, atrazine + simazine, ametryn, ethoxysulfuron, $S$-metolachlor, sulfentrazone e atrazine foram seletivos quando aplicados em pré-emergência em pastagem de capim-elefante.
\end{abstract}

Termos para indexação: Bioenergia; biocombustível; capim napier; forragem; Pennisetum purpureum.

\section{INTRODUCTION}

Elephant grass (Pennisetum purpureum Schum.), a member of the Poaceae family, is a perennial, rhizomatous grass native to tropical Africa (Schmelzer, 1997). It was introduced as forage in many tropical and subtropical regions of the world because of its ability to produce high biomass yield under a wide range of climatic and edaphic conditions (Aroeira et al., 2001) Elephantgrass is highly efficient in fixing atmospheric $\mathrm{CO}_{2}$ and able to accumulate more than $60 \mathrm{Mg} \mathrm{ha}^{-1}$ of dry matter per year (Morais et al., 2009).

Although elephant grass is mainly used as an animal feed (Santos et al., 2013; Rusdy, 2016), the high biomass production, especially in tropical countries, makes it a potential feedstock for bioenergy production (Flores et al., 2012; Ohimain; Kendabie; Nwachukwu, 2014; Sales et al., 2015). As a result, research has been directed to using elephant grass biomass for biofuel production such 
as charcoal (Strezov; Evans; Hayman, 2008), alcohol (Soares et al., 2011), methane, or even for direct burning (Samson et al., 2005; Lee et al., 2010). Elephant grass is similar to crushed sugarcane in terms of fiber content $(\sim$ $65 \%$ ), which is an important feature for the calorific value of biomass (Morais et al., 2009).

Weed interference is a major factor limiting elephant grass cultivation. The crop is sensitive to weed interference after planting (3-6 w) (Silva et al., 2002) because of its slow early development. Grass weeds, such as Brachiaria spp., are especially difficult to control selectively in elephant grass because of the morphological similarities between the two species (Abreu et al., 2006).

Because elephant grass is not only considered a crop, but also a weed species (Cutts et al., 2011; Odero; Gilbert, 2012; Grey et al., 2015), there is limited research on selective weed management in the crop. Currently, there are no herbicides registered for selective weed control elephant grass pasture. The objective of this study was to evaluate preemergence herbicides for potential selective weed control in elephant grass pastures.

\section{MATERIAL AND METHODS}

Two field experiments were conducted in 2014 and 2015 at Brazilian Agricultural Research Corporation (Embrapa) experimental fields in Valença, Rio de Janeiro State, Brazil $\left(22^{\circ} 22^{\prime} 06.30^{\prime \prime} \mathrm{S}, 43^{\circ} 42^{\prime} 00.62^{\prime \prime} \mathrm{W}\right)$ and Coronel Pacheco, Minas Gerais State, Brazil (21 $32^{\prime} 31.83^{\prime \prime} \mathrm{S}$, $\left.43^{\circ} 15^{\prime} 10.07^{\prime \prime} \mathrm{W}\right)$, respectively.
The soils in Valença and Coronel Pacheco were Red-Yellow Argisol and Fluvic Cambisol, respectively. The soil chemical properties and texture are listed in Table 1.

Average monthly air temperatures (maximum and minimum) and rainfall during the experimental periods are provided in Table 2.

The experimental design was a randomized complete block with four replications. The treatments included preemergence application of atrazine + $S$-metolachlor at $1.48+1.16 \mathrm{~kg}$ ai ha-1, atrazine + simazine at $1.5+1.5 \mathrm{~kg}$ ai ha-1, ametryn at $1.5 \mathrm{~kg}^{-1} \mathrm{ha}^{-1}$, ethoxysulfuron at $0.15 \mathrm{~kg}$ ai ha-1, $S$-metolachlor at 1.92 $\mathrm{kg}$ ai ha-1, diuron + hexazinone at $1.17+0.33 \mathrm{~kg}$ ai ha${ }^{1}$ sulfentrazone at $0.25 \mathrm{~kg}$ ai ha-1, imazethapyr at $0.1 \mathrm{~kg}$ ai $\mathrm{ha}^{-1}$, and atrazine at $2.0 \mathrm{~kg}$ ai ha- ${ }^{-1}$. Weedy and weed-free (hand-weeded) treatments were included.

The experimental plots were plowed and a disc harrows were used for smoothing out the surface of the soil before planting the elephant grass on October 30, 2014 and November 12, 2015 in Valença and Coronel Pacheco, respectively. Furrows $0.2 \mathrm{~m}$ deep with spacing of $1.0 \mathrm{~m}$ between rows were fertilized when planted using $200 \mathrm{~kg} \mathrm{ha}^{-1}$ of MAP (mono-ammonium phosphate). Stem cuttings of elephant grass cultivar BRS Capiaçu, $40 \mathrm{~cm}$ long with four buds per cutting were planted in the furrows and covered with approximately $15 \mathrm{~cm}$ of soil. Each plot was four furrows (rows) wide by $4 \mathrm{~m}$ in long. Plots were side-dressed with $40 \mathrm{~kg}$ of $\mathrm{N} \mathrm{ha}^{-1}$ (urea) 30 days after planting.

Table 1: Chemical analysis of the soil samples (0-20 cm depth) and soil texture properties.

\begin{tabular}{|c|c|c|c|c|c|c|c|c|c|c|}
\hline \multirow[t]{2}{*}{ Location } & \multirow{2}{*}{$\begin{array}{l}\mathrm{pH} \\
\mathrm{H}_{2} \mathrm{O}\end{array}$} & $\mathrm{P}$ & K & $\mathrm{Ca}^{2+}$ & $\mathrm{Mg}^{2+}$ & V & Sand & Silt & Clay & \multirow{2}{*}{$\begin{array}{c}\text { O.C } \\
\text { dag kg }\end{array}$} \\
\hline & & \multicolumn{2}{|c|}{$\mathrm{mg} \mathrm{dm}^{-3}$} & \multicolumn{2}{|c|}{$\mathrm{cmolc} \mathrm{dm}^{-3}$} & \multicolumn{4}{|c|}{$\%$} & \\
\hline Valença & 5.1 & 9.6 & 90 & 2.4 & 2.3 & 60 & 66 & 16 & 18 & 1.94 \\
\hline Coronel Pacheco & 4.8 & 15.2 & 109 & 2.3 & 1.1 & 46 & 30 & 25 & 45 & 2.46 \\
\hline
\end{tabular}

Table 2: Average maximum and minimum monthly air temperatures $(T)$, and rainfall during experiments conducted at Valença, Rio de Janeiro State, and Coronel Pacheco, Minas Gerais State, Brazil.

\begin{tabular}{|c|c|c|c|c|c|c|c|c|}
\hline \multirow{2}{*}{$\begin{array}{l}\text { Municipality } \\
\text { Month/Year }\end{array}$} & \multicolumn{4}{|c|}{ Valença } & \multicolumn{4}{|c|}{ Coronel Pacheco } \\
\hline & Oct/14 & Nov/14 & Dec/14 & Jan/15 & Nov/15 & Dec/15 & Jan/16 & Feb/16 \\
\hline Maximum $\mathrm{T}\left({ }^{\circ} \mathrm{C}\right)$ & 30.6 & 29.5 & 32.3 & 34.0 & 24.9 & 25.4 & 24.6 & 25.5 \\
\hline Minimum $\mathrm{T}\left({ }^{\circ} \mathrm{C}\right)$ & 17.0 & 19.1 & 20.3 & 20.4 & 23.7 & 24.0 & 23.4 & 24.0 \\
\hline Rainfall (mm) & 77.4 & 254.4 & 134.2 & 136.6 & 204.4 & 194.6 & 505.4 & 154.6 \\
\hline
\end{tabular}


Herbicide treatments were applied on November 4, 2014, in Valença before elephant grass and weed emergence and immediately after planting in Coronel Pacheco on November 12, 2015. The herbicides were applied using a $\mathrm{CO}_{2}$-pressurized backpack sprayer (Herbicat Ltda, Catanduva, São Paulo State, Brazil) calibrated to deliver $140 \mathrm{~L} \mathrm{ha}^{-1}$ of solution at $196 \mathrm{kPa}$. The spray boom ( $2 \mathrm{~m}$ length) was comprised of four flat-fan nozzles (Magno ADGA 11002) spaced $0.5 \mathrm{~m}$ apart. Sprayer boom height was adjusted to $0.5 \mathrm{~m}$ above the soil surface. Temperatures were 27 to $30^{\circ} \mathrm{C}$ and 29 to $32{ }^{\circ} \mathrm{C}$, relative humidity ranged from 68 to $75 \%$ and 78 to $82 \%$, and wind speeds were between 0.8 and $1.6 \mathrm{~m} \mathrm{~s}^{-1}$ and 0.6 to $1.4 \mathrm{~m} \mathrm{~s}^{-1}$ in Valença and Coronel Pacheco, respectively during the herbicide applications.

The phytotoxic effect of herbicide treatments on the elephant grass and weed control were evaluated on a scale of 0 to $100 \%$, with 0 being no injury or weed control and $100 \%$ being complete elephant grass death or complete weed control at 23 and 35 days after treatment (DAT) Sociedade Brasileira da Ciência das Plantas Daninhas (SBCPD, 1995).

Prevalent weed species and their densities before plowing the experimental area in Valença were alexandergrass (Brachiaria decumbens L.) (4.0 plants $\mathrm{m}^{-2}$ ), guineagrass (Panicum maximum Jacq.) (3.0 plants $\mathrm{m}^{-2}$ ), yellow nutsedge (Cyperus esculentus L.) (2.0 plants $\mathrm{m}^{-2}$ ), and benghal dayflower (Commelina benghalensis L.) (5.0 plants $\left.\mathrm{m}^{-2}\right)$. In Coronel Pacheco, the most prevalent weed species and their densities before plowing the experimental area were benghal dayflower (Commelina benghalensis L.) (4.0 plants $\left.\mathrm{m}^{-2}\right)$,

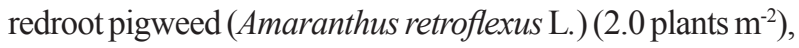

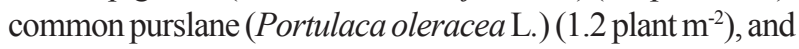
morninglory (Ipomoea grandifolia (Dammer) O'Donnell) (2.6 plants $\left.\mathrm{m}^{-2}\right)$.

Weed densities (plants $\mathrm{m}^{-2}$ ) were measured at 35 DAT at both study locations. All weed species were counted within a quadrat $(1.0 \times 1.0 \mathrm{~m})$. Weeds were cut from the soil surface using the same quadrat to determine aboveground biomass at 35 DAT for both experiments and again at 50 DAT in experiment conducted in Valença. Harvested weeds were weighed to determine fresh matter weight. The weeds collected at 80 DAT in Valença and at 35 DAT in Coronel Pacheco were placed in kraft paper bags and dried in a forced ventilation air oven at $65^{\circ} \mathrm{C}$ for $72 \mathrm{~h}$, reaching a constant mass. The dry matter was weighted on a graduated scale.

For both experiments, elephant grass green color indices were measured at 23 and 35 DAT by using a SPAD502 chlorophyll meter (Konica Minolta, Japan) and plant height was measured at 35 DAT. Elephant grass yield was measured at 80 DAT in both locations. Plants were cut within a quadrat $(1.0 \mathrm{x} 1.0 \mathrm{~m})$ at the soil surface to quantify aboveground biomass. Harvested plants were weighed, placed in a forced-air ventilation oven at $65^{\circ} \mathrm{C}$ for $72 \mathrm{~h}$, and subsequently reweighed. The values of fresh and dry matter weight of elephant grass were converted to $\mathrm{kg} \mathrm{ha}^{-1}$.

The percentage of phytoxicity and weed control data were normalized by square root transformation of $(x+1)$ to perform analysis of variance tests. Data were subjected to analysis of variance, and the mean values were compared using the Scott-Knott test $(P \leq 0.05)$. Statistical analyses were performed using the SAEG software for both experiments (Ribeiro Júnior, 2001).

\section{RESULTS AND DISCUSSION}

\section{Experiment conducted in Valença-RJ}

There was no phytotoxicity on elephant grass at 23 and 35 DAT following treatments with atrazine + $S$-metolachlor, atrazine + simazine, ametryn, ethoxysulfuron, $S$-metolachlor, and atrazine (Table 3).

Similarly, there was no injury on elephant grass cultivars Pioneiro and Cameron following preemergence atrazine $+S$-metolachlor and $S$-metolachlor (Silva et al., 2002). Both herbicides did not induce phytotoxic effects on the tested cultivars.

Sulfentrazone caused slight chlorosis on elephant grass leaves, resulting in $17 \%$ of phytotoxicity at 23 DAT. However, the phytotoxic effect of sulfentrazone was transient and no visual symptoms of injury at 35 DAT. In contrast, diuron + hexazinone and imazethapyr caused 81 and $70 \%$ injure on elephant grass at $35 \mathrm{DAT}$, respectively. Young leaves showed faint yellowing at 23 days after application of diuron + hexazinone. This symptom progressed to a stronger yellowing and necrosis of leaf blade at 35 DAT. Imazethapyr injury symptoms in elephant grass include yellow of leaf blade and leaf tips may appear red or purple in colour.

Atrazine $+S$-metolachlor, atrazine + simazine, ametryn, $S$-metolachlor, diuron + hexazinone, and sulfentrazone provided $95 \%$ to $100 \%$ weed control at 35 DAT. Silva et al. (2002) reported $91 \%$ grass control and $80 \%$ broadleaf weed control with $S$-metolachlor at $2.3 \mathrm{~kg}$ $\mathrm{ha}^{-1}$ in an elephant grass pasture. Application of atrazine and imazethapyr provided 59 and $81 \%$ weed control at $35 \mathrm{DAT}$, respectively. However ethoxysulfuron did not provide any weed control. Atrazine, imazethapyr, and ethoxysulfuron were not effective in controlling predominately grasses in the experimental plots. These herbicides have little to no 
Table 3: Percentage of phytotoxicity and weed control at 23 and 35 days after application of treatments at Valença, Rio de Janeiro State, Brazil.

\begin{tabular}{|c|c|c|c|c|c|}
\hline \multirow[t]{2}{*}{ Treatments } & \multirow{2}{*}{$\begin{array}{c}\text { Doses } \\
\left(\mathrm{kg} \mathrm{ha}^{-1}\right)\end{array}$} & \multicolumn{2}{|c|}{ Phytotoxicity (\%) } & \multicolumn{2}{|c|}{ Control (\%) } \\
\hline & & 23 & 35 & 23 & 35 \\
\hline Atrazine + S-metolachlor & $1.48+1.16$ & $0.0 \mathrm{D}^{1}$ & $0.0 \mathrm{C}$ & $95.0 \mathrm{~A}$ & $98.2 \mathrm{~A}$ \\
\hline Atrazine + Simazine & $1.5+1.5$ & $0.0 \mathrm{D}$ & $0.0 \mathrm{C}$ & $92.0 \mathrm{~A}$ & $95.0 \mathrm{~B}$ \\
\hline Ametryn & 1.5 & $0.0 \mathrm{D}$ & $0.0 \mathrm{C}$ & $98.2 \mathrm{~A}$ & $99.5 \mathrm{~A}$ \\
\hline Ethoxysulfuron & 0.15 & $0.0 \mathrm{D}$ & $0.0 \mathrm{C}$ & $7.7 \mathrm{D}$ & $0.0 \mathrm{E}$ \\
\hline S-metolachlor & 1.92 & $0.0 \mathrm{D}$ & $0.0 \mathrm{C}$ & $99.7 \mathrm{~A}$ & $100.0 \mathrm{~A}$ \\
\hline Diuron + hexazinone & $1.17+0.33$ & $71.0 \mathrm{~A}$ & $80.5 \mathrm{~A}$ & $99.2 \mathrm{~A}$ & $99.5 \mathrm{~A}$ \\
\hline Sulfentrazone & 0.25 & $17.0 \mathrm{C}$ & $0.0 \mathrm{C}$ & $99.5 \mathrm{~A}$ & $100.0 \mathrm{~A}$ \\
\hline Imazethapyr & 0.1 & $60.7 \mathrm{~B}$ & $69.5 \mathrm{~B}$ & $79.2 \mathrm{~B}$ & $80.7 \mathrm{C}$ \\
\hline Atrazine & 2.0 & $0.0 \mathrm{D}$ & $0.0 \mathrm{C}$ & $45.0 \mathrm{C}$ & $59.2 \mathrm{D}$ \\
\hline Weedy & - & $0.0 \mathrm{D}$ & $0.0 \mathrm{C}$ & $0.0 \mathrm{E}$ & $0.0 \mathrm{E}$ \\
\hline Weed-free & - & $0.0 \mathrm{D}$ & $0.0 \mathrm{C}$ & $100.0 \mathrm{~A}$ & $100.0 \mathrm{~A}$ \\
\hline Coefficient of Variation (\%) & & 1.4 & 1.0 & 3.0 & 1.4 \\
\hline
\end{tabular}

${ }^{1}$ Mean values followed by different letters are significantly $(P \leq 0.05)$ different by Scott-Knott test.

activity on grasses such as Brachiaria and are mainly used for broadleaf weed control (Rodrigues; Almeida, 2011). For example, atrazine applied at $1.5 \mathrm{~kg} \mathrm{ha}^{-1}$ did not have any effect on palisade grass (Brachiaria brizantha (Hochst. Ex A. Rich) Stapf.) intercropped with maize (Zea mays L.) (Jakelaitis et al., 2005). In this study, palisade grass had the highest biomass yield.

Weed density and fresh and dry matter weight were low for atrazine + S-metolachlor, atrazine + simazine, ametryn, S-metolachlor, diuron + hexazinone, and sulfentrazone treatments (Table 4). This fact confirms the efficacy of these herbicides in controlling weeds presented in this experiment.

Although atrazine and ethoxysulfuron showed selectivity on elephant grass species, they were not efficient in controlling weed species. Also, imazethapyr provided some level and weed control (81\%) but also cause phytotoxicity on elephant grass.

The treatments with atrazine $+S$-metolachlor, atrazine + simazine, ametryn, and $S$-metolachlor resulted in SPAD indice values equal to the weed-free treatment for both evaluations (Table 5).

Although, ethoxysulfuron and atrazine caused no visual injury symptoms on elephant grass plants, SPAD indice values were lower compared to weed-free treatment at 35 DAT. This was probably attributed to weed interference as a result of poor weed control by these treatments. Diuron + hexazinone, sulfentrazone, and imazethapyr caused yellowing on elephant grass leaves resulting in lower SPAD indice values at 35 DAT.

All treatments caused reduction in elephant grass plant height with the exception of atrazine + $S$-metolachlor. The weedy plots had the highest value for plant height, probably due to competition for light, which led to plant etiolation. Atrazine $+S$-metolachlor, atrazine + simazine, ametryn, $S$-metolachlor, and sulfentrazone provided significantly greater fresh and dry matter weight of elephant grass (Table 5). Atrazine + Simazine and $S$-metolachlor had higher values of fresh and dry matter weight of elephant grass than the weed-free treatment. In many cases, hand hoeing does not completely eliminate all weeds mainly within crop rows. Maybe, these weeds that established within elephant grass rows reduced the fresh and dry matter weight of the elephant grass in weed-free plots.

Although atrazine and ethoxysulfuron did not injure elephant grass, they did not provide weed control. This resulted in forage production losses manifested in the low fresh and dry matter weights. Diuron + hexazinone and imazethapyr also caused a reduction in fresh and dry matter of elephant grass due to their phytotoxic effects.

Weed interference on elephant grass occurred when no control measure was undertaken, i.e. for the weedy plots. The weedy plots produced $42 \%$ less elephant grass dry matter compared to the weed-free plots. 
Table 4: Density and fresh matter of weeds at 35 (FM35) and 50 (FM50) days after application of treatments (DAT) and dry matter of weeds at 80 DAT (DM80). Valença, Rio de Janeiro State, Brazil.

\begin{tabular}{|c|c|c|c|c|c|}
\hline Treatments & $\begin{array}{l}\text { Doses } \\
\left(\mathrm{kg} \mathrm{ha}^{-1}\right)\end{array}$ & $\begin{array}{c}\text { Density } \\
\text { (plants } \mathrm{m}^{-2} \text { ) }\end{array}$ & $\begin{array}{l}\text { FM35 } \\
\left(\mathrm{g} \mathrm{m}^{-2}\right)\end{array}$ & $\begin{array}{l}\text { FM50 } \\
\left(\mathrm{g} \mathrm{m}^{-2}\right)\end{array}$ & $\begin{array}{l}\text { DM80 } \\
\left(\mathrm{g} \mathrm{m}^{-2}\right)\end{array}$ \\
\hline Atrazine + S-metolachlor & $1.48+1.16$ & $1.0 \mathrm{C}^{1}$ & $0.43 \mathrm{D}$ & $0.77 \mathrm{C}$ & $0.13 \mathrm{C}$ \\
\hline Atrazine + Simazine & $1.5+1.5$ & $4.5 \mathrm{C}$ & $0.63 C$ & $0.97 \mathrm{C}$ & $0.16 \mathrm{C}$ \\
\hline Ametryn & 1.5 & $3.2 \mathrm{C}$ & $0.53 \mathrm{D}$ & $0.67 \mathrm{C}$ & $0.12 \mathrm{C}$ \\
\hline Ethoxysulfuron & 0.15 & $9.0 \mathrm{~B}$ & $3.81 \mathrm{~A}$ & $2.32 \mathrm{~A}$ & $0.44 \mathrm{~A}$ \\
\hline S-metolachlor & 1.92 & $4.0 \mathrm{C}$ & $0.29 \mathrm{D}$ & $0.32 \mathrm{C}$ & $0.06 \mathrm{C}$ \\
\hline Diuron + hexazinone & $1.17+0.33$ & $3.0 \mathrm{C}$ & $0.17 \mathrm{D}$ & $0.51 \mathrm{C}$ & $0.09 \mathrm{C}$ \\
\hline Sulfentrazone & 0.25 & $2.2 \mathrm{C}$ & $0.35 \mathrm{D}$ & $0.33 \mathrm{C}$ & $0.06 \mathrm{C}$ \\
\hline Imazethapyr & 0.1 & $3.7 \mathrm{C}$ & $0.79 \mathrm{C}$ & $1.27 \mathrm{~B}$ & $0.22 \mathrm{~B}$ \\
\hline Atrazine & 2.0 & $3.2 \mathrm{C}$ & $1.20 \mathrm{C}$ & $1.51 \mathrm{~B}$ & $0.28 \mathrm{~B}$ \\
\hline Weedy & - & $17.5 \mathrm{~A}$ & $2.24 \mathrm{~B}$ & $1.25 \mathrm{~B}$ & $0.25 \mathrm{~B}$ \\
\hline Weed-free & - & $0.0 \mathrm{C}$ & $0.00 \mathrm{D}$ & $0.00 \mathrm{C}$ & $0.05 \mathrm{C}$ \\
\hline Coefficient of Variation (\%) & & 59.3 & 36.4 & 45.5 & 40.4 \\
\hline
\end{tabular}

${ }^{1}$ Mean values followed by different letters are significantly $(P \leq 0.05)$ different by Scott-Knott test.

Table 5: SPAD indices at 23 and 35 days after application of the treatments (DAT), plant height at 35 DAT and fresh (FM) and dry (DM) matter weight of elephant grass at 80 DAT. Valença, Rio de Janeiro State. Brazil.

\begin{tabular}{cccccrr}
\hline \multirow{2}{*}{ Treatments } & $\begin{array}{c}\text { Doses } \\
\left(\mathrm{kg} \mathrm{ha}^{-1}\right)\end{array}$ & \multicolumn{2}{c}{ SPAD } & \multicolumn{1}{c}{$\begin{array}{c}\text { Height } \\
(\mathrm{m})\end{array}$} & $\begin{array}{c}\mathrm{FM} \\
\left(\mathrm{kg} \mathrm{ha}^{-1}\right)\end{array}$ & $\begin{array}{c}\mathrm{DM} \\
\left(\mathrm{kg} \mathrm{ha}^{-1}\right)\end{array}$ \\
\cline { 3 - 4 } & & 23 & 35 & & & \\
\hline Atrazine + S-metolachlor & $1.48+1.16$ & $60.8 \mathrm{~A}^{1}$ & $51.2 \mathrm{~A}$ & $1.21 \mathrm{~B}$ & $95,950 \mathrm{~B}$ & $20,017 \mathrm{~B}$ \\
Atrazine + Simazine & $1.5+1.5$ & $56.4 \mathrm{~A}$ & $51.8 \mathrm{~A}$ & $1.08 \mathrm{C}$ & $131,550 \mathrm{~A}$ & $30,085 \mathrm{~A}$ \\
Ametryn & 1.5 & $59.8 \mathrm{~A}$ & $52.1 \mathrm{~A}$ & $1.10 \mathrm{C}$ & $87,950 \mathrm{~B}$ & $18,512 \mathrm{~B}$ \\
Ethoxysulfuron & 0.15 & $43.4 \mathrm{~B}$ & $49.6 \mathrm{~B}$ & $1.01 \mathrm{D}$ & $30,250 \mathrm{E}$ & $6,234 \mathrm{C}$ \\
S-metolachlor & 1.92 & $56.0 \mathrm{~A}$ & $52.2 \mathrm{~A}$ & $1.04 \mathrm{C}$ & $120,050 \mathrm{~A}$ & $24,743 \mathrm{~A}$ \\
Diuron + hexazinone & $1.17+0.33$ & $41.3 \mathrm{~B}$ & $40.9 \mathrm{D}$ & $0.94 \mathrm{D}$ & $38,800 \mathrm{E}$ & $8,907 \mathrm{C}$ \\
Sulfentrazone & 0.25 & $43.1 \mathrm{~B}$ & $49.3 \mathrm{~B}$ & $0.97 \mathrm{D}$ & $102,375 \mathrm{~B}$ & $18,566 \mathrm{~B}$ \\
Imazethapyr & 0.1 & $57.4 \mathrm{~A}$ & $40.9 \mathrm{D}$ & $1.01 \mathrm{D}$ & $70,375 \mathrm{C}$ & $13,240 \mathrm{C}$ \\
Atrazine & 2.0 & $59.0 \mathrm{~A}$ & $46.0 \mathrm{C}$ & $1.00 \mathrm{D}$ & $57,200 \mathrm{D}$ & $11,793 \mathrm{C}$ \\
Weedy & - & $56.8 \mathrm{~A}$ & $33.8 \mathrm{E}$ & $1.40 \mathrm{~A}$ & $51,950 \mathrm{D}$ & $10,386 \mathrm{C}$ \\
Weed-free & - & $58.0 \mathrm{~A}$ & $52.3 \mathrm{~A}$ & $1.24 \mathrm{~B}$ & $99,925 \mathrm{~B}$ & $17,918 \mathrm{~B}$ \\
\hline Coefficient of Variation (\%) & & 5.2 & 4.7 & 5.5 & 11.7 & 22.6 \\
\hline
\end{tabular}

${ }^{1}$ Mean values followed by different letters are significantly $(P \leq 0.05)$ different by Scott-Knott test.

\section{Experiment conducted in Coronel Pacheco-MG}

Phytotoxicity of atrazine $+S$-metolachlor, atrazine + simazine, ametryn, ethoxysulfuron, $S$-metolachlor, sulfentrazone, and atrazine was low (2 to $14 \%$ ) at 23 DAT (Table 6).
By 35 DAT, there was no visual symptoms on elephant grass from these treatments. Diuron + hexazinone and imazethapyr caused 29 and $7 \%$ injury at 23 DAT. Phytotoxicity symptoms on elephant grass plants characterized by leaf chlorosis, tissue necrosis, and reduced plant height. Injury from diuron + hexazinone 
declined by $22 \%$ compared to a decline of $1 \%$ by imazehapyr at 35 DAT.

The phytotoxicity values were lower in the experiment conducted in Coronel Pacheco than in Valença. The soil of Coronel Pacheco had greater amount of clay and organic carbon when compared to the experiment conducted in Valença. Probably, great amount of herbicide was adsorbed on clay and organic carbon in Coronel Pacheco compared to Valença. Consequently, less herbicides were in the soil solution and available for the elephant grass, resulting in lower percentage of phytotoxicity.

Overall, all herbicide treatments provided acceptable weed control (89 to 100\%) at 35 DAT with the exception of ethoxysulfuron which provided only $11 \%$ control. Although ethoxysulfuron showed selectivity on elephant grass, it did not provide efficient weed control especially control of $C$. benghalensis which was predominant at the experimental site. This weed species is not effectively controlled by this herbicide (Rodrigues; Almeida, 2011). Diuron + hexazinone, sulfentrazone, and S-metolachlor were the most effective herbicides for weed control (provided 100\% control at 35 DAT).

All treatments significantly reduced weed density, fresh, and dry matter (Table 7).

The premix of atrazine $+S$-metolachlor applied on two elephant grass cultivars provided effective control of broadleaf weeds such as Sida glaziovii, Sida urens, and Acanthospermum australe (Silva et al., 2002).

SPAD indices were similar for the weed-free control and atrazine $+S$-metolachlor, atrazine + simazine, ametryn, ethoxysulfuron, $S$-metolachlor, sulfentrazone, and atrazine treatments at 35 DAT (Table 8).

Diuron + hexazinone and imazethapyr had mild chlorosis and had significantly lower SPAD indice values compared to the rest of the treatments at $35 \mathrm{DAT}$

Atrazine $+S$-metolachlor, ametryn, ethoxysulfuron, and atrazine did not cause reduction in plant height. The fresh and dry matter weights were not reduced in treatments containing atrazine $+S$-metolachlor, atrazine + simazine, ametryn, $S$-metolachlor, sulfentrazone, or atrazine. Although ethoxysulfuron did not caused injury on elephant grass plants, it was not efficient in weed control, thereby resulting in reduction in fresh matter and dry matter weight of elephant grass. Diuron + hexazinone and imazethapyr caused considerable reductions in the fresh and dry matter weights of the elephant grass in function of their phytotoxicity.

Elephant grass biomass reduction as a result of weed interference was evident when the weed-free and weedy controls were compared. Forage biomass losses were 44 and $41 \%$ for fresh and dry weight, respectively when no weed control measures were undertaken (weedy control) compared to weed-free control.

Table 6: Percentage of phytotoxicity and weed control at 23 and 35 days after application of treatments. Coronel Pacheco, Minas Gerais State, Brazil.

\begin{tabular}{|c|c|c|c|c|c|}
\hline \multirow[t]{2}{*}{ Treatments } & \multirow{2}{*}{$\begin{array}{l}\text { Doses } \\
\left(\mathrm{kg} \mathrm{ha}^{-1}\right)\end{array}$} & \multicolumn{2}{|c|}{ Phytotoxicity (\%) } & \multicolumn{2}{|c|}{ Control (\%) } \\
\hline & & 23 & 35 & 23 & 35 \\
\hline Atrazine + S-metolachlor & $1.48+1.16$ & $0.0 \mathrm{~F}^{1}$ & $0.0 \mathrm{C}$ & $94.2 \mathrm{~B}$ & $88.7 \mathrm{C}$ \\
\hline Atrazine + Simazine & $1.5+1.5$ & $2.0 \mathrm{E}$ & $0.0 \mathrm{C}$ & $92.2 \mathrm{~B}$ & $90.5 \mathrm{C}$ \\
\hline Ametryn & 1.5 & $2.2 \mathrm{E}$ & $0.0 \mathrm{C}$ & $91.7 \mathrm{~B}$ & $90.5 \mathrm{C}$ \\
\hline Ethoxysulfuron & 0.15 & $3.5 \mathrm{D}$ & $0.0 \mathrm{C}$ & $20.7 \mathrm{C}$ & $10.5 \mathrm{D}$ \\
\hline S-metolachlor & 1.92 & $2.5 \mathrm{E}$ & $0.0 \mathrm{C}$ & $99.5 \mathrm{~A}$ & $99.5 \mathrm{~A}$ \\
\hline Diuron + hexazinone & $1.17+0.33$ & $29.0 \mathrm{~A}$ & $6.7 \mathrm{~A}$ & $99.5 \mathrm{~A}$ & $100.0 \mathrm{~A}$ \\
\hline Sulfentrazone & 0.25 & $14.0 \mathrm{~B}$ & $0.0 \mathrm{C}$ & $99.0 \mathrm{~A}$ & $100.0 \mathrm{~A}$ \\
\hline Imazethapyr & 0.1 & $6.5 \mathrm{C}$ & $5.5 \mathrm{~B}$ & $90.0 \mathrm{~B}$ & $90.5 \mathrm{C}$ \\
\hline Atrazine & 2.0 & $2.7 \mathrm{E}$ & $0.0 \mathrm{C}$ & $91.0 \mathrm{~B}$ & $97.0 \mathrm{~B}$ \\
\hline Weedy & - & $0.0 \mathrm{~F}$ & $0.0 \mathrm{C}$ & $0.0 \mathrm{D}$ & $0.0 \mathrm{E}$ \\
\hline Weed-free & - & $0.0 \mathrm{~F}$ & $0.0 \mathrm{C}$ & $100.0 \mathrm{~A}$ & $100.0 \mathrm{~A}$ \\
\hline Coefficient of Variation (\%) & & 4.7 & 3.3 & 1.0 & 0.7 \\
\hline
\end{tabular}

${ }^{1}$ Mean values followed by different letters are significantly $(P \leq 0.05)$ different by Scott-Knott test. 
Table 7: Density and fresh (FM35) and dry (DM35) matter of weeds at 35 days after application of treatments. Coronel Pacheco, Minas Gerais State, Brazil.

\begin{tabular}{|c|c|c|c|c|}
\hline Treatments & $\begin{array}{c}\text { Doses } \\
\left(\mathrm{kg} \mathrm{ha}^{-1}\right)\end{array}$ & $\begin{array}{c}\text { Density } \\
\text { (plants } \mathrm{m}^{-2} \text { ) }\end{array}$ & $\begin{array}{l}\text { FM35 } \\
\left(\mathrm{g} \mathrm{m}^{-2}\right)\end{array}$ & $\begin{array}{l}\text { DM35 } \\
\left(\mathrm{g} \mathrm{m}^{-2}\right)\end{array}$ \\
\hline Atrazine + S-metolachlor & $1.48+1.16$ & $19.0 \mathrm{~B}^{1}$ & $39.3 \mathrm{C}$ & $16.1 \mathrm{~B}$ \\
\hline Atrazine + Simazine & $1.5+1.5$ & $11.2 \mathrm{C}$ & $24.3 \mathrm{C}$ & $11.8 \mathrm{~B}$ \\
\hline Ametryn & 1.5 & $8.5 \mathrm{C}$ & $58.1 \mathrm{C}$ & $16.5 \mathrm{~B}$ \\
\hline Ethoxysulfuron & 0.15 & $8.0 \mathrm{C}$ & $156.2 \mathrm{~B}$ & $26.6 \mathrm{~B}$ \\
\hline S-metolachlor & 1.92 & $2.5 \mathrm{D}$ & $17.0 \mathrm{C}$ & $8.9 \mathrm{~B}$ \\
\hline Diuron + hexazinone & $1.17+0.33$ & $0.0 \mathrm{D}$ & $0.0 \mathrm{C}$ & $0.0 \mathrm{~B}$ \\
\hline Sulfentrazone & 0.25 & $0.0 \mathrm{D}$ & $0.0 \mathrm{C}$ & $0.0 \mathrm{~B}$ \\
\hline Imazethapyr & 0.1 & $5.5 \mathrm{D}$ & $33.7 \mathrm{C}$ & $10.6 \mathrm{~B}$ \\
\hline Atrazine & 2.0 & $1.5 \mathrm{D}$ & $18.2 \mathrm{C}$ & $8.8 \mathrm{~B}$ \\
\hline Weedy & - & $58.2 \mathrm{~A}$ & $663.8 \mathrm{~A}$ & $119.9 \mathrm{~A}$ \\
\hline Weed-free & - & $0.0 \mathrm{D}$ & $0.0 \mathrm{C}$ & $0.0 \mathrm{~B}$ \\
\hline Coeficient of variation (\%) & & 47.9 & 48.0 & 53.0 \\
\hline
\end{tabular}

${ }^{1}$ Mean values followed by different letters are significantly $(P \leq 0.05)$ different by Scott-Knott test.

Table 8: SPAD indices at 23 and 35 days after application of the treatments, plant height and fresh (FM) and dry (DM) matter weight of elephant grass. Coronel Pacheco, Minas Gerais State, Brazil.

\begin{tabular}{ccccccc}
\hline Treatments & $\begin{array}{c}\text { Doses } \\
\left(\mathrm{kg} \mathrm{ha} \mathbf{-}^{-1}\right)\end{array}$ & \multicolumn{2}{c}{ SPAD } & $\begin{array}{c}\text { Height } \\
(\mathrm{m})\end{array}$ & $\begin{array}{c}\mathrm{FM} \\
\left(\mathrm{kg} \mathrm{ha}^{-1}\right)\end{array}$ & $\begin{array}{c}\mathrm{DM} \\
\left(\mathrm{kg} \mathrm{ha}^{-1}\right)\end{array}$ \\
\hline Atrazine + S-metolachlor & $1.48+1.16$ & $51.9 \mathrm{~A} 1$ & $52.2 \mathrm{~A}$ & $0.88 \mathrm{~A}$ & $145,950 \mathrm{~A}$ & $28,494 \mathrm{~A}$ \\
Atrazine + Simazine & $1.5+1.5$ & $48.9 \mathrm{~A}$ & $52.3 \mathrm{~A}$ & $0.82 \mathrm{~B}$ & $126,250 \mathrm{~A}$ & $24,040 \mathrm{~A}$ \\
Ametryn & 1.5 & $49.1 \mathrm{~A}$ & $53.0 \mathrm{~A}$ & $0.88 \mathrm{~A}$ & $134,400 \mathrm{~A}$ & $25,388 \mathrm{~A}$ \\
Ethoxysulfuron & 0.15 & $51.3 \mathrm{~A}$ & $51.3 \mathrm{~A}$ & $0.88 \mathrm{~A}$ & $113,050 \mathrm{~B}$ & $22,017 \mathrm{~B}$ \\
S-metolachlor & 1.92 & $41.6 \mathrm{~B}$ & $51.3 \mathrm{~A}$ & $0.83 \mathrm{~B}$ & $138,600 \mathrm{~A}$ & $26,346 \mathrm{~A}$ \\
Diuron + hexazinone & $1.17+0.33$ & $35.9 \mathrm{C}$ & $45.3 \mathrm{~B}$ & $0.67 \mathrm{C}$ & $87,200 \mathrm{C}$ & $17,213 \mathrm{~B}$ \\
Sulfentrazone & 0.25 & $35.0 \mathrm{C}$ & $51.7 \mathrm{~A}$ & $0.83 \mathrm{~B}$ & $148,900 \mathrm{~A}$ & $30,717 \mathrm{~A}$ \\
Imazethapyr & 0.1 & $31.9 \mathrm{C}$ & $40.2 \mathrm{C}$ & $0.56 \mathrm{D}$ & $103,300 \mathrm{~B}$ & $20,649 \mathrm{~B}$ \\
Atrazine & 2.0 & $50.7 \mathrm{~A}$ & $51.9 \mathrm{~A}$ & $0.91 \mathrm{~A}$ & $139,750 \mathrm{~A}$ & $28,783 \mathrm{~A}$ \\
Weedy & - & $52.6 \mathrm{~A}$ & $45.6 \mathrm{~B}$ & $0.70 \mathrm{C}$ & $72,275 \mathrm{C}$ & $15,645 \mathrm{~B}$ \\
Weed-free & - & $52.5 \mathrm{~A}$ & $52.7 \mathrm{~A}$ & $0.86 \mathrm{~A}$ & $128,050 \mathrm{~A}$ & $26,306 \mathrm{~A}$ \\
\hline Coefficient of variation (\%) & & 5.8 & 3.5 & 4.1 & 14.8 & 16.1
\end{tabular}

${ }^{1}$ Mean values followed by different letters are significantly $(P \leq 0.05)$ different by Scott-Knott test.

\section{CONCLUSIONS}

As an attempt to generate information useful for improving elephant grass utilization, this study reports on grass and broadleaf weed controls in this forages by using preemergence herbicides. Atrazine $+S$-metolachlor, atrazine + simazine, ametryn, ethoxysulfuron, $S$-metolachlor, sulfentrazone, and atrazine were selectives when applied in preemergence in elephant grass pasture. The treatments with diuron + hexazinone and imazethapyr were the most phytotoxic herbicides for the elephant grass. 
In both places, all treatments provided effective weed control, except ethoxysulfuron and atrazine in Valença-RJ and ethoxysulfuron in Coronel Pacheco-MG.

\section{ACKNOWLEDGEMENTS}

The financial support from Fundação de Amparo a Pesquisa do Estado de Minas Gerais (FAPEMIG) and the Conselho Nacional de Desenvolvimento Científico e Tecnológico $(\mathrm{CNPq})$ is highly appreciated.

\section{REFERENCES}

ABREU, J. G. et al. Glyphosate e nitrogênio no controle de Brachiaria decumbens STAPF em capineiras estabelecidas. Ciência e Agrotecnologia. 30(5):977-987, 2006.

AROEIRA, L. J. M. et al. Daily intake of lactating crossbred cows grazing elephant grass rotationally. Pesquisa Agropecuária Brasileira. 36(6):911-917, 2001.

CUTTS, G. S. et al. Herbicide effect on napier grass (Pennisetum purpureum) control. Weed Science. 59:255-262, 2011.

FLORES, R. A. et al. Yield and quality of elephant grass biomass produced in the Cerrados region for bioenergy. Engenharia Agrícola. 32(5):831-839, 2012.

GREY, T. L. et al. Evaluation of control of napier grass (Pennisetum purpureum) with tillage and herbicides. Invasive Plant Science \& Management. 8(4):393-400, 2015.

JAKELAITIS, A. et al. Efeitos de herbicidas no consórcio de milho com Brachiaria brizantha. Planta Daninha. 23(1):6978,2005

LEE, M. K. et al. Pyrolysis of napier grass in an induction-heating reactor. Journal of Analytical and Applied Pyrolysis. 88(2):110-116, 2010.

MORAIS, R. F. et al. Elephant grass genotypes for bioenergy production by direct biomass combustion. Pesquisa Agropecuária Brasileira. 44(2):133-144, 2009.

ODERO, D. C.; GILBERT, R. A. Dose-response of newly establish (Pennisetum purpureum) to postemergence herbicides. Weed Technology. 26(4):691-698, 2012.
OHIMAIN, E. I.; KENDABIE, P.; NWACHUKWU, R. E. S. Bioenergy potentials of elephant grass, Pennisetum purpureum Schumach. Annual Research \& Review in Biology. 4(13):2215-2227, 2014.

RIBEIRO JÚNIOR, J. I. Análises estatísticas no SAEG. Editora UFV, Viçosa: 2001, 301p.

RODRIGUES, B. N.; ALMEIDA, F. S. Guia de Herbicidas. 6. ed. Londrina, PR: Grafmarke. 2011. 697p.

RUSDY, M. Elephant grass as forage for ruminant animals. Livestock Research for Rural Development. 28(4), 2016. Available in: <http://www.Irrd.org/lrrd28/4/rusd28049. html>. Access in: 03 Oct. 2016.

SALES, F. A. et al. Biomass of elephant grass and leucena for bioenergy production. Semina: Ciências Agrárias. 36(6):3567-3578, 2015.

SAMSON, R. et al. The potential of $C_{4}$ perennial grasses for developing a global BIOHEAT industry. Critical Reviews in Plant Science. 24:461-495, 2005.

SANTOS, R. J. C. et al. Elephant grass clones for silage production. Scientia Agrícola. 70(1):6-11, 2013.

SOCIEDADE BRASILEIRA DA CIÊNCIA DAS PLANTAS DANINHAS - SBCPD. Procedimentos para instalação e análise de experimentos com herbicidas. Sociedade Brasileira da Ciência das Plantas Daninhas. Londrina. 1995. 42p.

SCHMELZER, G. H. Review of Pennisetum section Brevivalvula (Poaceae). Euphytica. 97(1):1-20, 1997.

SILVA, W. et al. Redução da interferência de Brachiaria decumbens na formação de pastagem de Pennisetum purpureum através de herbicidas. Planta Daninha. 20(2):273-281, 2002.

SOARES, I. B. et al. Ethanol production by enzymatic hydrolysis of elephant grass. Journal of Life Science. 5:157-161, 2011.

STREZOV, V.; EVANS, T. J.; HAYMAN, C. Thermal conversion of elephant grass (Pennisetum purpureum Schum.) to bio-gas, bio-oil and charcoal. Bioresource Technology. 99(17):8394-8399, 2008. 